\title{
Comparison of Epidural Steroid Injections with Conservative Management in Patients with Lumbar Radiculopathy
}

\author{
Rahman $\mathrm{MM}^{1}$, Rashid $\mathrm{MI}^{2}$, Rahman $\mathrm{N}^{3}$, Shakoor $\mathrm{MA}^{4}$
}

\begin{abstract}
Pain in the back is the most common of all chronic pain disorders. Back pain and sciatica, or leg pain originating from injury to or pressure on the sciatic nerve, are major causes of disability in adults, occurring in $15 \%$ to $20 \%$ of the working-age population annually and $70 \%$ to $90 \%$ of adults at some point in their lives. Men and women are affected equally. The study was conducted prospectively in 60 patients of 18 to 60 years of age with documented chronic low back pain with sciatica. Thirty patients were treated in group- $A$ with conservative treatment (NSAID + therapeutic exercises + superficial thermotherapy and ADL instruction) plus epidural steroid injection and 30 samples were treated in group $B$ with conservative treatment only.
\end{abstract}

Epidural steroid injection treatment group is significantly improved than conservative treatment group $(p<0.05)$. There was more improvement of pain in group $-A$ than in Group $B$ $(p=0.007)$ and SLR was more increased in group $-A$ than group- $B(p=0.03)$. So, epidural steroid injection is a effective treatment for lumber rediculopathy especially in acute phase.

\section{Key words : Lumber rediculopathy, epidural injection}

\section{Introduction}

Back pain is the most common of all chronic pain disorders. It may be originated from injury to or pressure on the sciatic nerve, are major causes of disability in adults, occurring in $15 \%$ to $20 \%$ of the working-age population annually and $70 \%$ to $90 \%$ of adults at some point in their lives. Men and women are affected equally. ${ }^{1}$

Sciatica is basically a nerve entrapment syndrome. As such, a local epidural steroid injection will reduce the soft tissue swelling, oedema, pressure, inflammation and soft

1. Corresponding Author: Dr. Md. Mahmudur Rahman, FCPS Assistant Professor, Physical Medicine \& Rehabilitation Bangabandhu Sheikh Mujib Medical University, Dhaka E-mail: nilumahmud@gmail.com

2. Dr. Md. Imamur Rashid, FCPS

Medical Officer, Physical Medicine \& Rehabilitation Bangabandhu Sheikh Mujib Medical University, Dhaka

3. Dr. Nadia Rahman, FCPS Medical Officer, Physical Medicine \& Rehabilitation Bangabandhu Sheikh Mujib Medical University, Dhaka

4. Dr. M A Shakoor, FCPS Associate Professor, Physical Medicine \& Rehabilitation Bangabandhu Sheikh Mujib Medical University, Dhaka adhesions $\mathrm{s}^{\mathbf{2 , 3}}$ on the nerve trunk $\mathrm{k}^{\mathbf{4 , 5 , 6}}$ as local steroid injections would do in other entrapment syndromes like carpal tunnel syndrome.

Management of chronic low back ache can be by two methods. Non invasive and invasive techniques: Non invasive technique include pharmacologic and non-pharmacologic approaches. Pharmacologic therapy includes use of various drugs such as Acetaminophen, NSAIDs, Opioid analgesics, Skeletal muscle relaxants, Tricyclic antidepressants, Gabapentin and others. Non pharmacologic therapy includes accupuncture, exercise therapy, massage, yoga, thermo therapy etc. Invasive methods include administration of epidural steroid injection and surgical intervention. Epidural injection of corticosteroids is one of the most commonly used interventions in managing chronic low back pain. Steroids presumably exert their effects by limiting inflammatory response, inhibiting leukocyte aggregation, preventing degranulation of inflammatory mediators, stabilizing lysosomal and other membranes, and reducing the synthesis and release of proinflammatory factors.

\section{Meterials and Methods}

The study was conducted prospectively in 60 patients of 18 to 60 years of age with documented chronic low back pain with sciatica at BSMMU, Popular Diagnosis Centre (Uttara and Narayangonj). Sixty patients were included in this study, 30 samples were group-A (NSAID+ therapeutic exercises + superficial thermotherapy and ADL instruction + Epidural steroid injection treatment) and 30 samples were group B conservative treatment (NSAID+ therapeutic exercises + superficial thermotherapy and ADL instruction). Patients in the epidural steroid injection treatment group were treated with $80 \mathrm{mg}$ of Depomedrol (methylprednisolone) in combination with $3 \mathrm{ml}$ of $2 \%$ plain xylocaine and $3 \mathrm{ml}$ of normal saline in the lumbar epidural space. Patients in the conservative group were treated with bed rest, non-steroidal anti-inflammatory agents, muscle relaxants, The exclusion criteria were patients refused to take epidural steroid injection and participated in this study, known contraindications for epidural steroid injections, infection, bleeding tendency or malignancy, patient's refusal, previous lumbar epidural steroid injections, previous lumbar spine surgery, unstable neurological deficits, cauda equine syndrome, high inflammatory marker (High ESR and C-Reactive protein) and local skin infection. All patients with lumbar radicular pain, having pretreatment visual analogue scale scoring of more than 6 and of more than 2 weeks duration, including low back and uni or bilateral leg pain were included in the study.

Data were processed manually and analyzed with the help of SPSS (Statistical package for social sciences) Version 19.0.Quantitative data were expressed as mean and standard deviation and comparison were done by student " $t$ " test. Qualitative were expressed as frequency and percentage and 
comparison, carried by chi-square $\left(\mathrm{X}^{2}\right)$ test. Other statistical test was done whenever it is necessary. A probability value (p) of less than 0.05 was considered to indicate statistical significance.

The predominant nerve root involved giving rise to sciatica symptoms was determined on clinical evidence and plain radiological findings. Gradings were recorded for pre-epidoral steroid injection(ESI) pain, parasthesia, and weakness, and measurements taken for ipsi-lateral and contra-lateral straight leg raising tests, and spinal motion (flexion and extension). One week post-ESI, the patient was reviewed and the same parameters were recorded for comparison and analysis. Pain and parasthesia improvements expressed in percentages, as subjectively judged by patients, and were also noted.

\section{Results}

In our study, age group of majority patients were in $3^{\text {rd }}$ to $5^{\text {th }}$ decad, which was $83.3 \%$ in group- A and $73.34 \%$ in group B ( Table-1).

Table-1 : Age group distribution of the study group

\begin{tabular}{|c|c|c|c|}
\hline \multirow[b]{2}{*}{ Age group } & \multicolumn{2}{|c|}{ Study group } & \multirow[b]{2}{*}{ Total } \\
\hline & Group-A n (\%) & Group-B n (\%) & \\
\hline (․ $30-40 \mathrm{yrs}$ & $16(53.3)$ & $14(46.67)$ & 30 \\
\hline$\square \quad 41-50 \mathrm{yrs}$ & $09(30.0)$ & $08(26.67)$ & 17 \\
\hline ( 51-60 yrs & $03(10.0)$ & $05(16.67)$ & 08 \\
\hline$\square \quad 61-70$ yrs & $02(6.67)$ & $03(10.0)$ & 05 \\
\hline Total & $30(100)$ & $30(100)$ & 60 \\
\hline
\end{tabular}

Table shows age groupdistribution of the study population, Majority age group were $3^{\text {rd }}$ to $5^{\text {th }}$ decad , which was $83.3 \%$ were group A and $73.34 \%$ in group B.

Table- 2 : Sex distribution of the study population

\begin{tabular}{|c|c|c|c|}
\hline \multirow[b]{2}{*}{ Sex } & \multicolumn{2}{|c|}{ Study group } & \multirow[b]{2}{*}{ Total } \\
\hline & Group-A n(\%) & Group-B n(\%) & \\
\hline Male & $11(36.67)$ & $13(43.33)$ & $24(40 \%)$ \\
\hline Female & $19(63.3)$ & $17(56.67)$ & $36(60 \%)$ \\
\hline Total & $30(100)$ & $30(100)$ & $60(100 \%)$ \\
\hline
\end{tabular}

Table shows female were predominant, $63.3 \%$ female was in group A and $56.67 \%$ female was group B. Thirty six percent male was group A and $43.3 \%$ male was group B.

Table 3 : Association between group $A$ and group B according to pre-ESI ipsilateral SLR test statuses

\begin{tabular}{llllll}
\hline & \multicolumn{3}{c}{ Study group } & & \\
\cline { 2 - 4 } & $\begin{array}{c}\text { Group-A } \\
\text { (injec) n(\%) }\end{array}$ & $\begin{array}{c}\text { Group-B } \\
\text { (cons) n(\%) }\end{array}$ & Total & P value \\
\hline SLR 15 $-30^{\circ}$ & $04(13.3)$ & $12(40.0)$ & 16 & $<0.03$ \\
SLR 35 $55^{\circ}-60^{\circ}$ & $16(53.3)$ & $13(43.3)$ & 29 & \\
SLR 65 $55^{\circ}-90^{\circ}$ & $10(36.7)$ & $05(16.7)$ & 16 & \\
Total & $30(100)$ & $30(100)$ & 60 & \\
\hline
\end{tabular}

Association between group A and group B according to preESI ipsilateral SLR test status, In group A (Injec) $13.3 \%$ was SLR $15^{\circ}-30^{\circ}, 53.3 \%$ was SLR $35^{\circ}-60^{\circ}$ and $36.7 \%$ was SLR $65^{\circ}-90^{\circ}$. In Group B (con) $40 \%$ was SLR $15^{\circ}-30^{\circ}, 43.3 \%$ was SLR $35^{\circ}-60^{\circ}$ and $16.7 \%$ was SLR $65^{\circ}-90^{\circ} .(\mathrm{p}<0.05)$ that was statistically significant.

Table 4: Pain improvement of the study population

\begin{tabular}{|c|c|c|c|c|}
\hline & \multicolumn{2}{|c|}{ Study group } & \multirow[b]{2}{*}{ Total } & \multirow[b]{2}{*}{ P value } \\
\hline & $\begin{array}{c}\text { Group-A } \\
\text { (injec) n(\%) }\end{array}$ & $\begin{array}{c}\text { Group-B } \\
\text { (cons) } \mathbf{n}(\%)\end{array}$ & & \\
\hline Poor & $03(10)$ & $09(30.0)$ & 12 & 0.007 \\
\hline Moderate & $04(13.3)$ & $11(36.67)$ & 15 & \\
\hline Good & $10(33.3)$ & $06(20.0)$ & 16 & \\
\hline Excellent & $13(43.3)$ & $04(13.3)$ & 17 & \\
\hline Total & $30(100)$ & $30(100)$ & 60 & \\
\hline
\end{tabular}

Table shows pain improvement of the study population, $43.3 \%$ pain excellent improvement was in group A and $13.3 \%$ pain excellent improvement was in group B. Good pain improved $33.3 \%$ in group A and $20 \%$ in group B, so group A treatment is significantly better than group B (p $<0.05$ ) that was statistically significant.

\section{Discussion}

The treatment of epidural steroid injection in sciatica is by no means a permanent cure, though quite a few patients had no more recurrences in their lifetime. Many countries and all continents with varying success as reported in the United Kingdom ${ }^{3,4}$, America $^{7}$, India ${ }^{8}$, Australia ${ }^{9}$, New Zealand ${ }^{\mathbf{1 0}}$ and Europe ${ }^{11}$. The most dreaded complication was epidural abscess $^{12}$ and localized infection of various forms ${ }^{13}$, whereas complications such as meningitis ${ }^{14}$ and $\operatorname{arachnoiditis}^{15}$ occurred rarely ${ }^{16}$ and only in subdural injections ${ }^{17}$ or not at all ${ }^{18}$. Other rare forms such as retinal haemorrhage, myopathy and lipomatosis associated with Cushing's syndrome have also been reported. ${ }^{19}$

SLR test discloses lumbosacral root tension. Normally it should be possible to raise the limb to $80^{\circ}$ to $90^{\circ}$. In this study, $28+11=39$ patients of both group showed significant increase of ipsilateral SLR. Both groups showed in the range of $20^{\circ}$ improvement of Ipsilateral SLR. ESI success rate is very encouraging (77\%) especially in acute cases and is mare or less same as with other studies like Epidural steroid injection for sciatica: an analysis of 526 consecutive cases with measurements. ${ }^{20}$

In study of Dinajpur done by Ahsan K and Mahmud SA reported results were divided according to preoperative pain grade. Twenty eight patients out of 36 in acute LBP group showed $77 \%$ pain improvement, 11 patients of chronic LBP group showed only $30 \%$ of pain improvement. Among 28 patients out of 36 in acute LBP group showed $77 \%$ pain improvement and 11 patients out of 36 of chronic LBP group showed only $30 \%$ of pain improvement. So, it is concluded that epidural steroid injection is a simple, cost effective and minimally invasive treatment for LBP especially in acute phase. ${ }^{21}$ 


\section{Reference}

1. Crow WT, Willis DR. Estimating cost of care for patients with acute low back pain: a retrospective review of patient records. J Am Osteopath Assoc. 2009;109(4):229-233.

2. Davis R, Emmons SE. Benefits of epidural methylprednisolone in a unilateral lumbar discectomy: A matched controlled study. J of Spinal Disorders. 1990 3 (4):299-307.

3. Dilke TF, Burry HC, Grahame R. Extradural corticosteroid injection in management of lumber nerve root compression. Br Med J 1973 Jun 16; 2 (867)): 6357.

4. Bogduk N. Spine update - Epidural Steroids. Spine 1995;7:845-8.

5. Feffer HL. Regional use of steroids in the management of lumbar intervertebral disc disease. Orth Clin of N Am 19756 (1):249-253.

6. Ryan MD, Taylor TK. Management of lumbar nerve root pain by intrathecal and epidural injections of depot methylprednisolone acetate. Med J Aust. 1981 Nov 14; 2 (10): 532-4.

7. Carette S, Leclaire R, Marcoux S, Morin F,. Blaise GA, St.-Pierre A, Truchon R, Parent F, Levesque J, Bergeron V, Montminy P, Blanchette C. Epidural Corticosteroid Injections for Sciatica Due to Herniated Nucleus Pulposus. N Eng J Med 1997;336:1634-40

8. Mam MK. Results of epidural injection of local anaesthetic and corticosteroid in patients with lumbosciatic pain. J Indian Med Assoc 1995 Jan;93 (1):17-8.

9. Corrigan AB, Carr G, Tugwell S. Intraspinal corticosteroid injections. Med J Aust 1982;1:224-5.

10. Hickey RF. Outpatient epidural steroid injections for low back pain and lumbarsacral radiculopathy. NZ Med J 1987 ;100 (832): 594-6.
11. Koes BW, Scholten RJ, Mens JM, Bouter LM. Efficacy of epidural steroid injections for low-back pain and sciatica: a systematic review of randomized clinical trials. Pain 1995 Dec;63 (3):279-288.

12. Bromage PR. Extradural abscesses. Comment. Br J Anaesth 1993 Apr.70 (4): 387-8.

13. Knight JW, Cordingley JJ, Palazzo MG. Epidural abscess following epidural steroid and local anaesthetic injection. Anaesthesia 1997 Jun;52 (6):576-8.

14. Nelson DA. Dangers from methylprednisolone acetate therapy by intraspinal injection. Comments in: Arch Neurol 1989 Jul;46 (7): 718-91, 719-2, 721-2, 1989 Nov;46 (11):1167-8.

15. Roche J. Steroid-induced arachnoiditis. Med J Aust, 1984 Mar 3, 281-4.

16. Bradley KC, Corrigan AB, Ingpen ML. Letter to editor. Med J Aust. 1982 Jan 9:11-12.

17. Katz JA, Lukin R, Bridenbaugh PO, Gunzenhauser L. Sudural Intracranial air: An unusual course of headache after epidural injection. Anesthesiology. 1991 Mar; 74 (3): $615-8$.

18. Maxwell DC. Letter to editor. Med J Aust. 1991 Mar 18 154:428-9.

19. Roy-Camille R, Mazel C, Husson JL, Saillant G. Symptomatic spinal epidural lipomatosis induced by a long-term steroid streatment. Review of the literature and report of two additional cases. Spine 1991 Dec. 16 (12): 1365-71.

20. Campbell's Operative Orthopaedics 7th Ed. 1987 Crenshaw AH Vol 4: 3293-4. The C.V. Mosby Co., St. Louis, USA.

21. Ahsan K, Mahmud SA. A Clinical Trial of Epidural Steroid Injection (ESI) in the Treatment of Low Back Pain Dinajpur Med Col J 2011;4(1):26-30. 